\title{
Phenolic compounds, bioactive content and antioxidant capacity of the fruits of mulberry (Morus spp.) germplasm in Turkey
}

\author{
Muttalip Gundogdu ${ }^{1 *}$, Ihsan Canan', Mustafa K. Gecer' ${ }^{2}$, \\ Tuncay Kan ${ }^{3}$, Sezai Ercisli ${ }^{4}$
}

${ }^{1}$ Department of Horticulture, Faculty of Agriculture and Natural Sciences Abant Izzet Baysal University, Bolu, 14030, Turkey

${ }^{2}$ Department of Horticulture, Faculty of Agriculture Igdır University, Igdır, Turkey

${ }^{3}$ Department of Horticulture, Faculty of Agriculture Inonu University, Malatya, Turkey

${ }^{4}$ Department of Horticulture, Faculty of Agriculture Ataturk University, Erzurum, Turkey

\begin{abstract}
The study was carried out in 2014 and 2015, and aimed to determine some important biochemical and antioxidant characteristics of the fruits of mulberry (Morus spp.) cultivars and genotypes found in Malatya (Turkey). Phenolic compounds (protocatechuic acid, vanillic acid, ellagic acid, rutin, quercetin, gallic acid, catechin, chlorogenic acid, caffeic acid, syringic acid, $p$-coumaric acid, $o$-coumaric acid, phloridzin and ferulic acid), organic acids, sugars, vitamin $C$ and antioxidant capacity were analyzed in sampled fruits. The results showed that most of the biochemical content and antioxidant capacities of the cultivars and genotypes were significantly different from one another $(p<0.05)$. Among the phenolic compounds, rutin $\left(118.23 \mathrm{mg} 100 \mathrm{~g} \mathrm{~g}^{-1}\right)$, gallic acid $\left(36.85 \mathrm{mg} 100 \mathrm{~g}^{-1}\right)$, and chlorogenic acid $\left(92.07 \mathrm{mg} 100 \mathrm{~g} \mathrm{~g}^{-1}\right)$ were determined to have the highest values for most of the fruit samples. Malic acid and citric acid were dominant among the organic acids for all the cultivars and genotypes except 44-Nrk-05. Glucose was measured as a more abundant sugar than fructose and sucrose in all samples. Antioxidant capacity, on the other hand, varied between 6.17

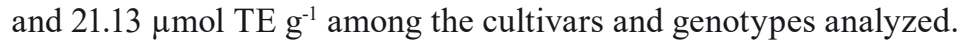

Key words: cultivar, genotype, mulberry, phytochemicals

\section{INTRODUCTION}

Fruit growing is one of the important and paying branches of horticulture, and has been practiced in most countries of the world for centuries. It is one of the important income sources of the main fruitgrowing countries. Fruit species have been used not only for nutrition purposes but also to meet personal and social needs such as curing diseases, beautifying the planet, etc. (Hegedus et al. 2010, Canan et al. 2016, Sorkheh and Khaleghi 2016, Zorenc et al. 2016).

Mulberry was cultivated especially for sericulture at first, but then became a fruit species with ever-increasing popularity along with the 
increased use of it also in human nutrition, food, and pharmaceutical industries. Mulberry has a wide distribution area in regions with tropical, semitropical, or temperate climates, thanks to its high adaptation ability (Ercisli and Orhan 2007, Ercisli and Orhan 2008, Orhan and Ercisli 2010). Four mulberry species, namely Morus rubra, Morus nigra, Morus alba and Morus laevigata, have grown naturally in Turkey for many years and show high diversity (Ercisli 2004, Ozgen et al. 2009). In recent years, an increasing number of studies have been conducted on mulberry fruits in relation to morphological, biochemical, phytochemical and antioxidant characteristics, and their contribution to human nutrition and health (Ercisli and Orhan 2007, Koyuncu et al. 2014, Sanchez et al. 2014, SanchezSalcedo et al. 2015). Mulberry fruits are generally consumed fresh or dried, and are also used as raw material in numerous branches of industry producing, for example, sorbet, fruit juice, wine, milk, yogurt, ice cream, vinegar, marmalade, jam, molasses, fruit leather, churchkhela (locally named Mulberry Kome), cosmetics, and pharmaceuticals in mulberry-growing countries, including Turkey (Gungor and Sengul 2008, Gundogdu et al. 2011). In addition to fresh consumption, black and red mulberries are extensively used for making jam, juice and marmalade; whereas white mulberries, which constitute $95 \%$ of mulberries in Turkey, are consumed as dried fruit (4\%), used in making molasses (70\%) and kome, a special local mulberry product $(10 \%)$, or eaten fresh $(5 \%)$ (Ercisli 2004).

Mulberries, especially the black and purplecoloured ones, are a very rich source of anthocyanins (Ercisli and Orhan 2008). White mulberries, which are rich in flavonoids, are also known as an important nutritional source for protecting the immune system (Butt et al. 2008). Previous studies had revealed that phenolic compounds having a protective effect in coronary heart disease and some types of cancer are also anti-aging owing to their antioxidant characteristics instrumental in eliminating free radicals (Rodriguez-Mateos et al. 2014). Because of its high phytochemical content, the black mulberry fruit has been used in folk medicine from old times against several disorders such as nausea, vomiting, digestive disorders, diabetes, hypertension, coughs, anaemia, arthritis, mouth sores, gingival diseases, fever, and fatigue (Gungor and Sengul 2008). Organic acids and sugars contribute to the taste of product, especially in fresh fruits. In addition to increasing the attractiveness of mulberry fruits for consumption, these components, along with antioxidant substances, have found use in diverse areas of pharmacology (Soyer et al. 2003). Chemical content and antioxidant capacity of fruits are influenced by numerous factors. In particular, environmental conditions and genotype structure have great effects on the formation of these substances (Mikulic-Petkovsek et al. 2012, Sanchez et al. 2014). It has been revealed in several studies that the quality of local products made of particular wild or semi-wild edible fruits is also improved as a result of the high level of chemical components in mulberry species growing naturally in various regions of Turkey (Ercisli and Orhan 2008, Ozgen et al. 2009, Gundogdu et al. 2011, Orhan and Ercisli 2010). Mulberry consumption per capita is also increasing day by day as a result of these characteristics. According to data of the Turkish Statistical Institute, annual mulberry production in Turkey reached 69.334 tons in 2016 (TSI 2016).

Genetic variation is the main prerequisite for a breeding programme for horticultural crop plants in the world. Therefore, investigation of the genetic source of variation among genotypes and commercial cultivars of different fruit species is always critical to the initiation of a breeding programme. Most of the mulberry species found in Turkey consist of wild and old trees. Production of mulberry fruit occurs in almost every region of Anatolia. Limited information exists in the literature about the biochemical status of the mulberry genotypes in Turkey. In Turkey, active mulberry breeding has increased in the last decades and Turkish breeders are facing problems in the use of some novel sources of variation in their breeding programmes due to the lack of information about the biochemical properties of the available genotypes. Therefore, this study can be a starting point to investigate new genotypes with better biochemical characteristics. In this study, certain foreign mulberry cultivars and local genotypes of mulberry growing in Turkey were analyzed. Anti-cancer phenolic compounds, organic acids, and antioxidant capacity are the most important quality criteria of mulberry fruits, especially in terms of human health. Therefore, we believe that this study will serve as a novel source of variation for Turkish and international breeders searching for variations to develop novel commercial cultivars with a high antioxidant capacity and phenolic content. 


\section{MATERIAL AND METHODS}

\section{Experimental site description}

The weather data for both years are given below (Fig. 1). The fertilization practices, pest and disease management, and irrigation were conducted properly in each year. Location of the experimental site: $38^{\circ} 21^{\prime} \mathrm{N}$ and $38^{\circ} 20^{\prime} \mathrm{E}$, with an altitude of $973 \mathrm{~m}$ above sea level.

\section{Fruit samples}

In this study, eight standard foreign mulberry cultivars originated in China, Japan and South Korea, and eleven mulberry genotypes from Turkey were used. The important plant characteristics of the cultivars and genotypes are given in Table 1.

The plants were grown together in the National Fruit Genetics Resources Plot of the Malatya Fruit
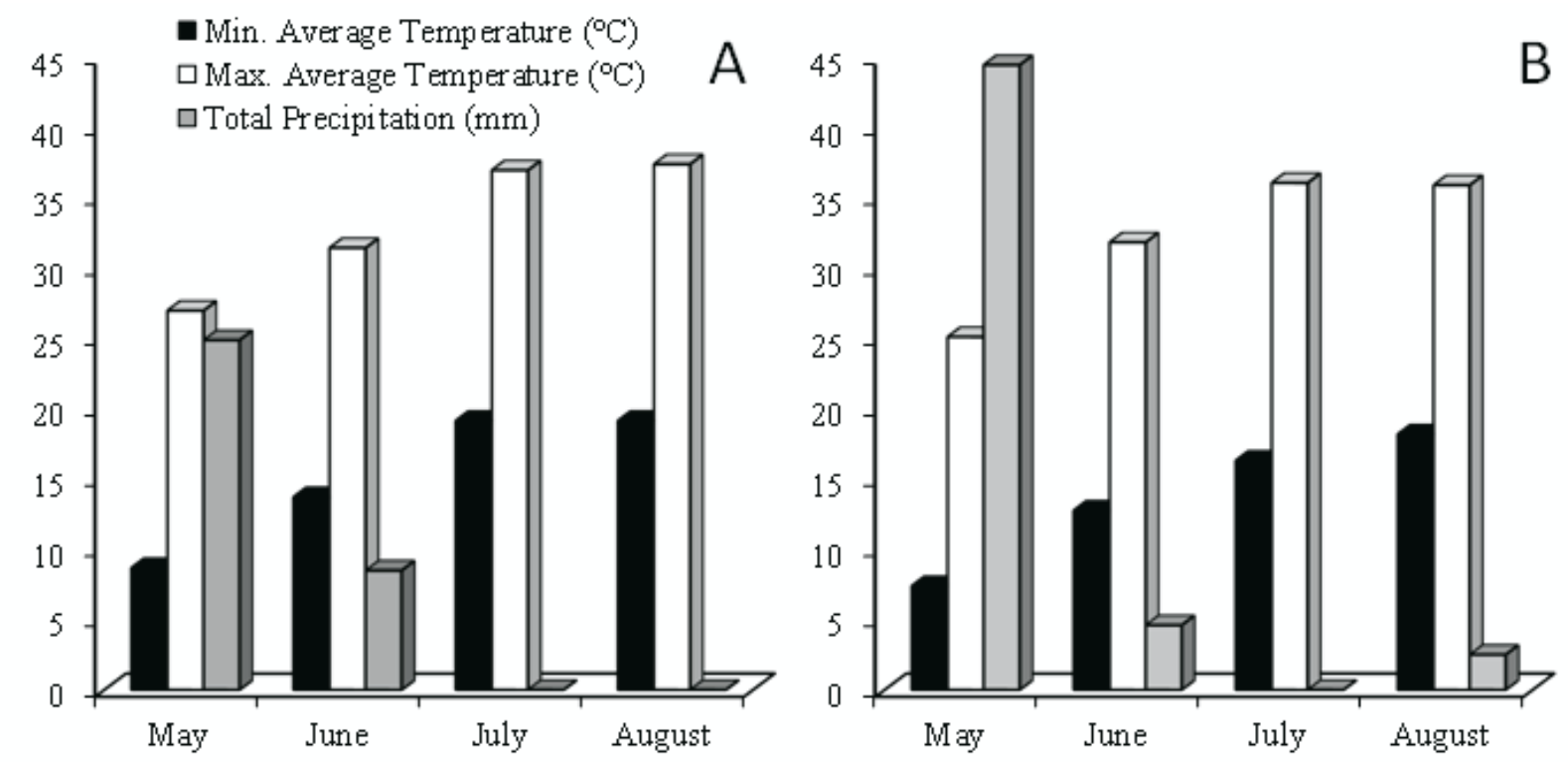

Figure 1. Weather parameters of the experimental mulberry-growing area for 2014 year (A) and 2015 (B) (Malatya province)

Table 1. Some important plant characteristics of mulberry cultivars and genotypes

\begin{tabular}{llcc}
\hline Cultivar/Genotype & Species & Origin & Fruit colour \\
\hline Angut-Bayırbağ & Morus alba & Erzincan, Turkey & White \\
Elaziğ-Çekirdekli & Morus alba & Elaziğ,Turkey & White \\
Istanbul-dut (24-10) & Morus alba & Erzincan, Turkey & White \\
44-MRK-05 & Morus alba & Malatya, Turkey & White \\
Arapgir-0011 & Morus alba & Malatya, Turkey & White \\
Arapgir-0012 & Morus alba & Malatya, Turkey & White \\
44-KE-10 & Morus alba & Malatya, Turkey & White \\
24-MRK-01 & Morus alba & Erzincan, Turkey & White \\
24-KE-05 & Morus alba & Erzincan, Turkey & Black \\
23-MRK-09 & Morus nigra & Elaziğ, Turkey & Black \\
44-BA-05 & Morus nigra & Malatya, Turkey & Black \\
Ship Yeoung & Not known & South Korea & Black \\
Suwean Daeyap & Not known & South Korea & Black \\
Roso & Not known & South Korea & Black \\
Yong Cheanchoe & Not known & South Korea & Black \\
Gosho Eromi & Not known & Japan & White \\
Thengxiang & Morus alba & China & Japan \\
Kokusa 20 & Not known & China & Black \\
He ye bar & Not known & & \\
\hline
\end{tabular}


Research Institute. Harvesting was performed in both 2014 and 2015 when the fruits of the investigated cultivars and genotypes had reached the commercial ripe stage. Approximately $1 \mathrm{~kg}$ fruit samples were taken from each cultivar and genotype. Fruit samples were collected at the same time and were stored at $-80^{\circ} \mathrm{C}$ until analyses were performed.

\section{Chemicals}

Organic acid standards (oxalic, citric, malic, succinic, fumaric, and tartaric acid), phenolic acid standards (gallic, chlorogenic, $O$-coumaric, $p$-coumaric, ferulic, vanillic, syringic, caffeic, ellagic and protocatechuic acid), polyphenols standards (catechin, phloridzin, quercetin, rutin), sugar standards (glucose, fructose, and sucrose), and vitamin $\mathrm{C}$ standard (L-ascorbic acid) were obtained from Sigma-Aldrich (St. Louis, MO, 71 USA). The other chemicals were obtained from Merck (Darmstadt, Germany) unless otherwise indicated.

\section{Analysis of phenolic compounds}

Protocatechuic, gallic, chlorogenic, ellagic, caffeic, $p$-coumaric, $o$-coumaric, vanillic, syringic and ferulic acids as well as catechin, rutin, quercetin and phloridzin were detected among phenolic compounds in mulberry fruits, with the modified method of Rodriguez-Delgado et al. (2001) and Gundogdu et al. (2011). Fruit extracts were mixed with distilled water in a ratio of $1: 1$. The mixture was centrifuged for $15 \mathrm{~min}$. at 15,000 rpm. Supernatants were filtrated with a coarse filter paper and twice with a $0.45 \mu \mathrm{m}$ membrane filter (Millipore Millex-HV Hydrophilic PVDF, Millipore, USA), and injected into an HPLC (Agilent, USA). Chromatographic separation was performed with a $250 \times 4.6 \mathrm{~mm}, 4 \mu \mathrm{m}$ ODS column (HiChrom, USA). Solvent A - methanol : acetic acid : water (10:2:28) and Solvent B - methanol : acetic acid : water (90:2:8) were used as the mobile phase (Tab. 2). Spectral measurements were made

Table 2. Gradient elution programme for the determination of phenolic compounds in mulberry fruit

\begin{tabular}{lcc}
\hline $\begin{array}{l}\text { Time } \\
(\min .)\end{array}$ & $\begin{array}{c}\text { Dissolvent A } \\
(\%)\end{array}$ & $\begin{array}{c}\text { Dissolvent B } \\
(\%)\end{array}$ \\
\hline 0 & 100 & 0 \\
15 & 85 & 15 \\
25 & 50 & 50 \\
35 & 15 & 85 \\
45 & 0 & 100 \\
\hline
\end{tabular}

at 254 and $280 \mathrm{~nm}$, and the flow rate and injection volume were adjusted to $1 \mathrm{~mL} \min ^{-1}$ and $20 \mu \mathrm{L}$, respectively.

\section{Analysis of organic acids}

Succinic, oxalic, citric, malic, fumaric, and tartaric acids contents of berries were determined according to Bevilacqua and Califano (1989). Three replicates including 30 fruits per replicate were used. Juice extracts were obtained by mashing the berries in cheesecloth, after which the samples were stored at $-20^{\circ} \mathrm{C}$ until analysed. $5 \mathrm{~mL}$ of each sample was mixed with $20 \mathrm{~mL}$ of $0.009 \mathrm{~N} \mathrm{H}_{2} \mathrm{SO}_{4}$ (Heidolph Silent Crusher M, Germany), then homogenized for 1 hour with a shaker (Heidolph Unimax 1010, Germany). The mixture was centrifuged for 15 min. at 15,000 rpm, and supernatants were filtrated twice with a $0.45 \mu \mathrm{m}$ membrane filter following filtration with a coarse filter (Millipore MillexHV Hydrophilic PVDF, Millipore, USA) and run through a SEP-PAK C18 cartridge. Organic acid readings were performed with HPLC using an Aminex column (HPX-87 H, $300 \times 7.8 \mathrm{~mm}$, BioRad Laboratories, Richmond, CA, USA) at 214 and $280 \mathrm{~nm}$ wavelengths, controlled with the Agilent package program (Agilent, USA).

\section{Analysis of vitamin C}

Vitamin $\mathrm{C}$ content was detected with a modified HPLC procedure suggested by Cemeroglu (2007). $5 \mathrm{~mL}$ of the fruit extracts was supplemented with $2.5 \%(\mathrm{w} / \mathrm{v})$ metaphosphoric acid (Sigma, M6285, $33.5 \%$ ), then centrifuged at $6,500 \mathrm{rpm}$ for $10 \mathrm{~min}$. at $4^{\circ} \mathrm{C} .0 .5 \mathrm{~mL}$ of the mixture was brought to the final volume of $10 \mathrm{~mL}$ with $2.5 \%(\mathrm{w} / \mathrm{v})$ metaphosphoric acid. Three replicates including 30 fruits per replicate were used. Supernatants were filtered with a $0.45 \mu \mathrm{m}$ PTFE syringe filter (Phenomenex, UK). $\mathrm{C}_{18}$ column (Phenomenex Luna C18, $250 \times$ $4.60 \mathrm{~mm}, 5 \mu$ ) was used for the identification of ascorbic acid at a temperature of $25^{\circ} \mathrm{C}$. Double distilled water with $1 \mathrm{~mL} \mathrm{~min}{ }^{-1}$ flow rate and $\mathrm{pH}$ of 2.2 (acidified with $\mathrm{H}_{2} \mathrm{SO}_{4}$ ) was used as a mobile phase. Spectral measurements were made at 254 nm wavelength using DAD detector. Different standards of L-ascorbic acid (Sigma A5960) (50, $100,500,1000$, and $2000 \mathrm{ppm}$ ) were used for the quantification of ascorbic acid readings.

\section{Determination of trolox equivalent antioxidant capacity (TEAC)}

Trolox equivalent antioxidant capacity (TEAC) was determined with ABTS (2,2-Azino-bis-3ethylbenzothiazoline-6-sulfonic acid) radical cation 
by dissolving ABTS in an acetate buffer using potassium persulphate (Ozgen et al. 2006). Three replicates including 30 fruits per replicate were used. For longer stability, the mixture was diluted with $20 \mathrm{mM}$ sodium acetate buffer in an acidic $\mathrm{pH}$ of 4.5, and read at $734 \mathrm{~nm}$ wavelength, $0.700 \pm 0.01$.

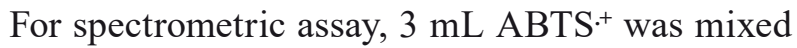
with $20 \mu \mathrm{L}$ fruit extract sample and incubated for 10 min. Absorbance was read at $734 \mathrm{~nm}$ wavelength.

\section{Sugar analysis}

The modified method of Melgarejo et al. (2000) was used for sugar (fructose, glucose and sucrose) analyses. Three replicates including 30 fruits per replicate were used. $5 \mathrm{~mL}$ of fruit extracts was centrifuged at $12,000 \mathrm{rpm}$ for 2 minutes at a temperature of $4^{\circ} \mathrm{C}$. Supernatants were passed by SEP-PAK $\mathrm{C}_{18}$ cartridge. HPLC readings were made with $\mu$ bondapak- $\mathrm{NH}_{2}$ column using $85 \%$ acetonitrile as liquid phase with refractive index detector (IR). Fructose and glucose standards were used for sugar calculations.

\section{Statistical analysis}

Three replicates including 30 fruits per replicate were used. Descriptive statistics of phenolic compounds, organic acids, sugars, vitamin $\mathrm{C}$, and antioxidant capacity extracted from cultivars and genotypes were represented as the mean \pm SE. Experimental data were evaluated using analysis of variance (ANOVA), and significant differences among the means of three replicates $(p<0.05)$ were determined by Duncan's multiple range test using the SPSS 20 for Windows.

\section{RESULTS AND DISCUSSION}

\section{Phenolic compounds}

Phenolic compounds such as protocatechuic acid, vanillic acid, ellagic acid, rutin, quercetin, gallic acid, catechin, chlorogenic acid, caffeic acid, syringic acid, $p$-coumaric acid, $o$-coumaric acid, phloridzin, and ferulic acid varied in all the cultivars and genotypes at a statistically significant level, $p<0.05$ (Tabs 3 and 4). Among the studied phenolic compounds, chlorogenic acid was dominant in the fruits of Ship Yeoung, Suwean Daeyap, Yong Choenchoe, Gosho Eromi, Kokusa-20, 23-MRK-09, Angut Bayırbağı, Elazığ Çekirdekli, İstanbul-dut (24-10), 44-MRK-05, Arapgir-0011, Arapgir-0012, 44-KE-10, 24-MRK-01, 24-KE-05, and rutin dominated in Roso, Thengxiang, He ye bar, 23MRK-09 and 44 BA-05.

Table 3. Protocatechuic acid, vanillic acid, ellagic acid, rutin, quercetin, gallic acid and catechin contents ( $\mathrm{mg}^{\left.100 \mathrm{~g}^{-1}\right)}$ of mulberry cultivars and genotypes (mean for 2014 and 2015)

\begin{tabular}{|c|c|c|c|c|c|c|c|}
\hline $\begin{array}{l}\text { Cultivars and } \\
\text { genotypes }\end{array}$ & $\begin{array}{l}\text { Protocatechu- } \\
\text { ic acid }\end{array}$ & $\begin{array}{l}\text { Vanillic } \\
\text { acid }\end{array}$ & $\begin{array}{l}\text { Ellagic } \\
\text { acid }\end{array}$ & Rutin & Quercetin & $\begin{array}{c}\text { Gallic } \\
\text { acid }\end{array}$ & Catechin \\
\hline Ship Yeoung & $1.33 \pm 0.02 \mathrm{~g}^{*}$ & $0.24 \pm 0.00 \mathrm{i}$ & $4.78 \pm 0.03 c$ & $32.73 \pm 1.07 \mathrm{i}$ & $7.73 \pm 0.04 c$ & $13.95 \pm 0.05 \mathrm{o}$ & $3.47 \pm 0.07 \mathrm{i}$ \\
\hline Suwean Daeyap & $0.82 \pm 0.001$ & $1.13 \pm 0.03 \mathrm{e}$ & $2.89 \pm 0.05 f$ & $44.90 \pm 0.12 \mathrm{~g}$ & $2.16 \pm 0.01 \mathrm{k}$ & $36.85 \pm 0.25 \mathrm{a}$ & $2.13 \pm 0.021$ \\
\hline Roso & $0.71 \pm 0.02 \mathrm{~m}$ & $1.76 \pm 0.03 \mathrm{c}$ & $4.99 \pm 0.03 b$ & $109.94 \pm 0.64 b$ & $1.89 \pm 0.011$ & $22.00 \pm 0.10 \mathrm{i}$ & $9.27 \pm 0.06 \mathrm{~b}$ \\
\hline Yong Choenchoe & $1.46 \pm 0.02 \mathrm{f}$ & $1.08 \pm 0.01 \mathrm{f}$ & $2.76 \pm 0.06 \mathrm{~g}$ & $60.00 \pm 0.35 f$ & $1.09 \pm 0.02 \mathrm{n}$ & $24.10 \pm 0.40 \mathrm{~g}$ & $2.04 \pm 0.03 \mathrm{~m}$ \\
\hline Gosho Eromi & $2.71 \pm 0.04 b$ & $0.40 \pm 0.01 \mathrm{~h}$ & $4.32 \pm 0.05 \mathrm{~d}$ & $37.78 \pm 0.45 \mathrm{~h}$ & $1.18 \pm 0.01 \mathrm{~m}$ & $12.85 \pm 0.15 p$ & $2.14 \pm 0.061$ \\
\hline Thengxiang & $3.78 \pm 0.08 \mathrm{a}$ & $1.32 \pm 0.02 \mathrm{~d}$ & $3.95 \pm 0.04 \mathrm{e}$ & $79.64 \pm 1.35 \mathrm{c}$ & $2.76 \pm 0.05 \mathrm{j}$ & $23.30 \pm 0.30 \mathrm{~h}$ & $9.85 \pm 0.06 \mathrm{a}$ \\
\hline Kokusa 20 & $1.62 \pm 0.03 \mathrm{~d}$ & $2.03 \pm 0.02 b$ & $2.45 \pm 0.04 \mathrm{~h}$ & $59.74 \pm 0.73 \mathrm{f}$ & & $28.10 \pm 0.70 \mathrm{e}$ & $3.78 \pm 0.02 \mathrm{~h}$ \\
\hline He ye bar & $0.87 \pm 0.02 \mathrm{k}$ & $0.85 \pm 0.03 \mathrm{~g}$ & $5.21 \pm 0.04 \mathrm{a}$ & $118.23 \pm 1.37 \mathrm{a}$ & $6.64 \pm 0.02 \mathrm{e}$ & $19.60 \pm 0.10 \mathrm{k}$ & $5.21 \pm 0.08 \mathrm{e}$ \\
\hline 23-mrk-09 & $1.55 \pm 0.03 \mathrm{e}$ & $0.24 \pm 0.001 \mathrm{i}$ & $2.00 \pm 0.02 \mathrm{i}$ & $75.78 \pm 0.65 d$ & $0.98 \pm 0.01 \mathrm{o}$ & $36.30 \pm 0.10 b$ & $8.02 \pm 0.06 c$ \\
\hline 44-ba-05 & $1.62 \pm 0.04 \mathrm{~d}$ & $3.86 \pm 0.05 \mathrm{a}$ & $1.62 \pm 0.06 \mathrm{j}$ & $68.78 \pm 0.37 \mathrm{e}$ & $2.15 \pm 0.02 \mathrm{k}$ & $14.95 \pm 0.35 n$ & $3.83 \pm 0.03 \mathrm{~h}$ \\
\hline Angut-Bayırbağ 1 & $1.72 \pm 0.02 \mathrm{c}$ & $0.17 \pm 0.01 \mathrm{j}$ & $1.22 \pm 0.03 \mathrm{k}$ & $28.37 \pm 0.45 \mathrm{k}$ & $6.81 \pm 0.02 \mathrm{~d}$ & $15.98 \pm 0.03 \mathrm{~m}$ & $1.78 \pm 0.04 n$ \\
\hline Elazığ-Çekirdekli & $1.46 \pm 0.01 \mathrm{f}$ & $0.88 \pm 0.02 \mathrm{~g}$ & $0.74 \pm 0.03 n$ & $29.74 \pm 0.33 j$ & $10.42 \pm 0.02 \mathrm{a}$ & $31.10 \pm 0.07 \mathrm{c}$ & $2.33 \pm 0.02 \mathrm{k}$ \\
\hline İstanbul-dut (24-10) & $1.13 \pm 0.02 \mathrm{i}$ & $0.21 \pm 0.001 \mathrm{i}$ & $1.16 \pm 0.01 \mathrm{kl}$ & $20.81 \pm 0.21 \mathrm{~m}$ & $5.12 \pm 0.01 \mathrm{~h}$ & $18.20 \pm 0.231$ & $1.13 \pm 0.02 p$ \\
\hline 44-MRK-05 & $1.08 \pm 0.02 \mathrm{j}$ & $0.09 \pm 0.00 \mathrm{k}$ & $1.04 \pm 0.03 \mathrm{~m}$ & $22.45 \pm 0.091$ & $4.19 \pm 0.03 i$ & $19.67 \pm 0.24 \mathrm{k}$ & $1.32 \pm 0.04 \mathrm{o}$ \\
\hline Arapgir-0011 & $1.57 \pm 0.01 \mathrm{ed}$ & $0.03 \pm 0.001$ & $1.17 \pm 0.01 \mathrm{kl}$ & $28.38 \pm 0.47 \mathrm{k}$ & $6.46 \pm 0.03 \mathrm{f}$ & $29.40 \pm 0.23 \mathrm{~d}$ & $4.83 \pm 0.07 f$ \\
\hline Arapgir-0012 & $1.68 \pm 0.05 c$ & $0.17 \pm 0.01 \mathrm{j}$ & $1.22 \pm 0.06 \mathrm{k}$ & $27.33 \pm 0.11 \mathrm{k}$ & $6.45 \pm 0.01 \mathrm{f}$ & $26.27 \pm 0.27 f$ & $4.31 \pm 0.08 \mathrm{~g}$ \\
\hline 44-KE-10 & $1.42 \pm 0.03 \mathrm{f}$ & $0.06 \pm 0.00 \mathrm{kl}$ & $1.20 \pm 0.01 \mathrm{k}$ & $32.85 \pm 0.20 \mathrm{i}$ & $6.38 \pm 0.01 \mathrm{~g}$ & $24.27 \pm 0.34 \mathrm{~g}$ & $7.05 \pm 0.11 \mathrm{~d}$ \\
\hline 24-MRK-01 & $1.43 \pm 0.04 \mathrm{f}$ & $0.08 \pm 0.01 \mathrm{k}$ & $1.12 \pm 0.021$ & $10.54 \pm 0.08 \mathrm{n}$ & $7.93 \pm 0.11 b$ & $21.43 \pm 0.87 j$ & $2.51 \pm 0.06 \mathrm{j}$ \\
\hline 24-KE-05 & $1.23 \pm 0.01 \mathrm{~h}$ & $0.05 \pm 0.001$ & $1.12 \pm 0.031$ & $30.01 \pm 0.24 j$ & $6.81 \pm 0.05 \mathrm{~d}$ & $30.58 \pm 0.09 \mathrm{c}$ & $2.02 \pm 0.02 \mathrm{~m}$ \\
\hline
\end{tabular}

*Difference between means designated with the same letter in the same column is not significant at 0.05 level 
Table 4. Chlorogenic acid, caffeic acid, syringic acid, p-coumaric acid, o-coumaric acid, phloridzin, and ferulic acid contents (mg $100 \mathrm{~g}^{-1}$ ) of mulberry cultivars and genotypes (mean for 2014 and 2015)

\begin{tabular}{|c|c|c|c|c|c|c|c|}
\hline $\begin{array}{l}\text { Cultivars and } \\
\text { genotypes }\end{array}$ & $\begin{array}{l}\text { Chlorogenic } \\
\text { acid }\end{array}$ & $\begin{array}{l}\text { Caffeic } \\
\text { acid }\end{array}$ & $\begin{array}{l}\text { Syringic } \\
\text { acid }\end{array}$ & $\begin{array}{l}p \text {-coumaric } \\
\text { acid }\end{array}$ & $\begin{array}{c}o \text {-coumaric } \\
\text { acid }\end{array}$ & Phloridzin & $\begin{array}{l}\text { Ferulic } \\
\text { acid }\end{array}$ \\
\hline Ship Yeoung & $40.75 \pm 0.80 \mathrm{~h}^{*}$ & $9.98 \pm 0.06 f$ & $3.55 \pm 0.06 \mathrm{k}$ & $3.76 \pm 0.05 \mathrm{c}$ & $1.68 \pm 0.08 \mathrm{j}$ & $0.16 \pm 0.00 \mathrm{j}$ & $2.74 \pm 0.03 \mathrm{c}$ \\
\hline Suwean Daeyap & $87.56 \pm 1.25 b$ & $4.66 \pm 0.02 \mathrm{~m}$ & $1.83 \pm 0.07 \mathrm{~m}$ & $2.31 \pm 0.03 \mathrm{f}$ & $3.22 \pm 0.01 \mathrm{~h}$ & $0.93 \pm 0.03 \mathrm{c}$ & $1.67 \pm 0.01 \mathrm{~h}$ \\
\hline Roso & $61.02 \pm 0.99 \mathrm{e}$ & $9.74 \pm 0.01 \mathrm{~g}$ & $7.05 \pm 0.06 \mathrm{de}$ & $5.67 \pm 0.07 \mathrm{a}$ & $6.17 \pm 0.09 \mathrm{a}$ & $0.48 \pm 0.01 \mathrm{~g}$ & $0.76 \pm 0.02 \mathrm{~m}$ \\
\hline Yong Choenchoe & $92.07 \pm 0.07 \mathrm{a}$ & $9.67 \pm 0.04 \mathrm{~g}$ & $6.97 \pm 0.06 \mathrm{e}$ & $2.09 \pm 0.06 \mathrm{~g}$ & $3.66 \pm 0.03 \mathrm{e}$ & $0.26 \pm 0.01 \mathrm{i}$ & $1.41 \pm 0.02 \mathrm{jk}$ \\
\hline Gosho Eromi & $39.62 \pm 0.97 \mathrm{~h}$ & $5.90 \pm 0.06 \mathrm{k}$ & $3.06 \pm 0.071$ & $3.87 \pm 0.04 \mathrm{c}$ & $1.71 \pm 0.03 \mathrm{j}$ & $0.16 \pm 0.00 \mathrm{j}$ & $1.43 \pm 0.05 \mathrm{jk}$ \\
\hline Thengxiang & $73.84 \pm 0.24 d$ & $5.67 \pm 0.071$ & $6.10 \pm 0.03 f$ & $3.40 \pm 0.45 \mathrm{~d}$ & $4.82 \pm 0.04 \mathrm{~b}$ & $0.66 \pm 0.03 f$ & $1.73 \pm 0.04 \mathrm{gh}$ \\
\hline Kokusa 20 & $78.90 \pm 8.70 c$ & $15.82 \pm 0.02 \mathrm{~d}$ & $7.04 \pm 0.04 \mathrm{de}$ & $2.04 \pm 0.06 \mathrm{~g}$ & $4.48 \pm 0.05 \mathrm{~d}$ & $0.79 \pm 0.03 \mathrm{~d}$ & $1.77 \pm 0.02 \mathrm{~g}$ \\
\hline He ye bar & $24.84 \pm 0.79 j$ & $6.97 \pm 0.16 \mathrm{j}$ & $4.72 \pm 0.04 \mathrm{i}$ & $4.79 \pm 0.03 b$ & $4.71 \pm 0.04 \mathrm{c}$ & $0.17 \pm 0.01 \mathrm{j}$ & $1.48 \pm 0.02 \mathrm{j}$ \\
\hline 23-mrk-09 & $71.76 \pm 0.27 \mathrm{~d}$ & $16.11 \pm 0.04 \mathrm{c}$ & $10.75 \pm 0.05 b$ & $1.48 \pm 0.02 \mathrm{ij}$ & $3.56 \pm 0.05 f$ & $0.42 \pm 0.04 \mathrm{~h}$ & $1.39 \pm 0.01 \mathrm{k}$ \\
\hline 44-ba-05 & $85.40 \pm 2.80 \mathrm{~b}$ & $21.09 \pm 0.06 \mathrm{a}$ & $7.11 \pm 0.13 \mathrm{~d}$ & $1.31 \pm 0.08 \mathrm{j}$ & $3.48 \pm 0.07 \mathrm{~g}$ & $0.11 \pm 0.00 \mathrm{k}$ & $1.57 \pm 0.04 \mathrm{i}$ \\
\hline Angut-Bayırbağ1 & $40.60 \pm 0.50 \mathrm{~h}$ & $4.34 \pm 0.02 \mathrm{o}$ & $1.16 \pm 0.02 \mathrm{n}$ & $1.62 \pm 0.01 \mathrm{hi}$ & $0.88 \pm 0.011$ & $0.75 \pm 0.02 \mathrm{e}$ & $0.98 \pm 0.011$ \\
\hline Elazı̆ğ-Çekirdekli & $45.96 \pm 1.68 \mathrm{~g}$ & $15.86 \pm 0.05 \mathrm{~d}$ & $8.22 \pm 0.04 \mathrm{c}$ & $2.68 \pm 0.06 \mathrm{e}$ & $0.48 \pm 0.01 \mathrm{n}$ & $1.15 \pm 0.03 \mathrm{a}$ & $2.67 \pm 0.04 \mathrm{c}$ \\
\hline İstanbul-dut (24-10) & $33.03 \pm 0.13 i$ & $2.44 \pm 0.01 \mathrm{r}$ & $11.91 \pm 0.12 \mathrm{a}$ & $1.73 \pm 0.00 \mathrm{~h}$ & $0.38 \pm 0.00 \mathrm{o}$ & $0.63 \pm 0.03 f$ & $4.79 \pm 0.09 \mathrm{a}$ \\
\hline 44-MRK-05 & $32.23 \pm 0.03 \mathrm{i}$ & $4.47 \pm 0.06 n$ & & $2.71 \pm 0.01 \mathrm{e}$ & $0.53 \pm 0.02 \mathrm{n}$ & $0.91 \pm 0.02 \mathrm{c}$ & $2.99 \pm 0.10 \mathrm{~b}$ \\
\hline Arapgir-0011 & $42.74 \pm 1.36 \mathrm{gh}$ & $7.67 \pm 0.01 \mathrm{i}$ & $3.92 \pm 0.09 j$ & $0.76 \pm 0.01 \mathrm{k}$ & $0.77 \pm 0.01 \mathrm{~m}$ & $1.09 \pm 0.05 b$ & $2.20 \pm 0.05 \mathrm{e}$ \\
\hline Arapgir-0012 & $57.33 \pm 1.61 \mathrm{e}$ & $11.27 \pm 0.04 \mathrm{e}$ & $3.93 \pm 0.04 j$ & $0.78 \pm 0.01 \mathrm{k}$ & $0.40 \pm 0.01 \mathrm{o}$ & $0.63 \pm 0.02 f$ & $2.37 \pm 0.07 d$ \\
\hline 44-KE-10 & $51.69 \pm 0.91 \mathrm{f}$ & $17.28 \pm 0.13 b$ & $5.45 \pm 0.06 \mathrm{~h}$ & $0.72 \pm 0.02 \mathrm{k}$ & $3.10 \pm 0.04 i$ & $0.41 \pm 0.00 \mathrm{~h}$ & $2.02 \pm 0.07 \mathrm{f}$ \\
\hline 24-MRK-01 & $41.28 \pm 1.50 \mathrm{~h}$ & $3.89 \pm 0.06 p$ & $5.77 \pm 0.04 \mathrm{~g}$ & $0.70 \pm 0.01 \mathrm{k}$ & $1.17 \pm 0.04 \mathrm{k}$ & $1.13 \pm 0.02 \mathrm{a}$ & $1.68 \pm 0.06 \mathrm{~h}$ \\
\hline 24-KE-05 & $30.79 \pm 0.05 \mathrm{i}$ & $8.55 \pm 0.01 \mathrm{~h}$ & $1.16 \pm 0.03 n$ & $0.71 \pm 0.02 \mathrm{k}$ & $3.27 \pm 0.04 \mathrm{~h}$ & $0.17 \pm 0.00 \mathrm{j}$ & $1.70 \pm 0.02 \mathrm{gh}$ \\
\hline
\end{tabular}

*Difference between means designated with the same letter in the same column is not significant at 0.05 level

Memon et al. (2010) had reported that chlorogenic

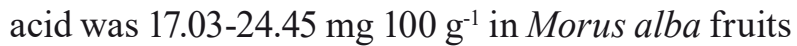

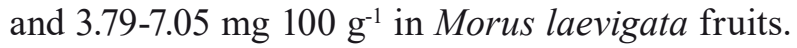
In the studies by Gundogdu et al. (2011) and Eyduran et al. (2015), chlorogenic acid and rutin were determined as the major two phenolic compounds in mulberry fruits, which is in agreement with our study. Gecer et al. (2016) had determined rutin at a level of $1.22 \mathrm{mg} \mathrm{g}^{-1}$ in black mulberry fruits and $2.37 \mathrm{mg} \mathrm{g}^{-1}$ of chlorogenic acid in white mulberry fruits at the highest level. Chlorogenic acid has been reported to be formed by the esterification of caffeic acid and quinic acid (Çam and Hisil 2004). Zadernowski et al. (2005) determined that phenolic compounds imparting taste in ripening berry fruits were affected by genetic factors and pre-harvest conditions. In addition, genetic factors, ecological factors (moisture, light, temperature, and soil structure), and cultivation practices can also be regarded as factors that affect phenolic compounds in mulberry fruits (Gundogdu et al. 2011).

The Istanbul-dut (24-10) genotype was found to have a higher syringic acid content than the other cultivars and genotypes. The caffeic acid and vanillic acid contents of the 44b-Ba-05 genotype were higher than in the other genotypes and standard varieties. The measured amount of protocatechuic acid was the highest in the Thengxiang cultivar (3.78 mg $100 \mathrm{~g}^{-1}$ ) and the lowest in the Roso

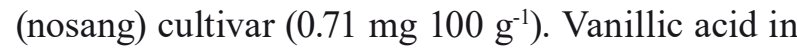
the fruits of the mulberry cultivars and genotypes was between $0.24 \mathrm{mg} 100 \mathrm{~g} \mathrm{~g}^{-1}$ and $2.03 \mathrm{mg} 100 \mathrm{~g}^{-1}$, with the 44-ba-05 genotype containing the highest amount of $3.86 \mathrm{mg} 100 \mathrm{~g}^{-1}$. The amount of ellagic acid was found to have the highest value of 5.21 $\mathrm{mg} 100 \mathrm{~g}^{-1}$ in the He ye bar cultivar and the lowest value of $0.74 \mathrm{mg} 100 \mathrm{~g}^{-1}$ in the Elazığ-çekirdekli genotype. The cultivar He ye bar had the highest

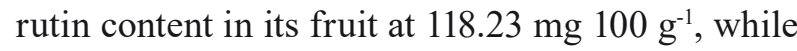
the 24-MRK-01 genotype had the lowest value of $10.54 \mathrm{mg} 100 \mathrm{~g}^{-1}$. The quercetin content was determined to have the highest value of $10.42 \mathrm{mg}$ $100 \mathrm{~g}^{-1}$ in the Elazı $\breve{g}$-çekirdekli genotype, and the

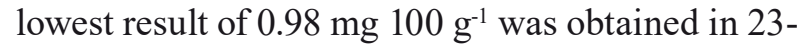
Mrk-09. Gallic acid and catechin were measured in the ranges of $12.85-36.85 \mathrm{mg} 100 \mathrm{~g}^{-1}$ and 1.13$9.85 \mathrm{mg} 100 \mathrm{~g}^{-1}$, respectively, among the cultivars and genotypes (Tab. 3). On the other hand, the chlorogenic acid content was determined to be at the highest level of $92.07 \mathrm{mg}_{100 \mathrm{~g}^{-1}}$ in the Yong choenchoe cultivar; the lowest level of $24.84 \mathrm{mg}$ $100 \mathrm{~g}^{-1}$ was determined in the He ye bar cultivar. 
The highest caffeic acid content was $21.09 \mathrm{mg}$ $100 \mathrm{~g}^{-1}$ in the 44-BA-05 genotype; its lowest value was $2.44 \mathrm{mg} 100 \mathrm{~g}^{-1}$ in the İstanbul-dut (24-10) genotype. In turn, the highest syringic acid content

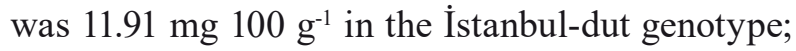
its lowest value was $1.16 \mathrm{mg} 100 \mathrm{~g}^{-1}$ in the genotypes Angut and 24-KE-05. The $p$-coumaric acid content was measured to be higher in the cultivars than in the genotypes and its highest value was $5.67 \mathrm{mg}$ $100 \mathrm{~g}^{-1}$ in the Roso cultivar, whereas the lowest amounts of $p$-coumaric acid were contained in 24-MRK-01, 24-KE-05, 44-KE-10, Arapgir-0011 and Arapgir-0012. The highest $o$-coumaric acid content was determined in Roso, while the lowest value was found in Istanbul-dut (24-10). The phloridzin content was higher in the genotypes than in the cultivars, and its highest value was $1.15 \mathrm{mg}$ $100 \mathrm{~g}^{-1}$ in the fruits of the Elazı $\breve{g}$-çekirdekli genotype. In terms of ferulic acid content, the Istanbul-dut genotype gave the best result with 4.79 mg $100 \mathrm{~g}^{-1}$. Gundogdu et al. (2011) had measured the amounts of gallic acid, catechin, caffeic acid, syringic acid, $p$-coumaric acid, ferulic acid, $o$-coumaric acid, vanillic acid, rutin, and quercetin as $0.15,0.08,0.13,0.10,0.13,0.06,0.13,0.04,1.42$, and $0.11 \mathrm{mg} \mathrm{g}^{-1}$ in black mulberry fruits, and as
$0.22,0.04,0.12,0.13,0.05,0.05,0.03,0.02,0.01$, and $0.02 \mathrm{mg} \mathrm{g}^{-1}$ in white mulberry fruits, respectively, which shows similarities with our study.

By using three different extraction methods, i.e. sonication, magnetic stirring and homogenization, Memon et al. (2010) had obtained the reported phenolics from Morus alba fruits as follows: gallic acid 3.57-5.81 mg $100 \mathrm{~g}^{-1}$, protocatechuic acid 2.30-

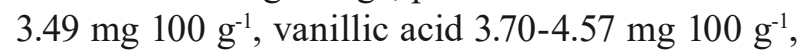
syringic acid 6.31-9.19 mg $100 \mathrm{~g} \mathrm{~g}^{-1}$; and from Morus laevigata fruits as follows: gallic acid $9.69-10.88 \mathrm{mg}$ $100 \mathrm{~g}^{-1}$, protocatechuic acid 1.67-5.61 mg $100 \mathrm{~g} \mathrm{~g}^{-1}$, vanillic acid 4.63-8.20, syringic acid 3.94-8.11 $\mathrm{mg}$

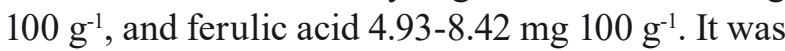
thought that the variations in the concentration of the phenolic compounds might have been associated with the use of the different extraction methods.

In this research, it was determined that the genotypes 44-BA-05, Istanbul-dut, 24-MRK-01 and 44-BA-05 showed promising characteristics when compared to standard cultivars in terms of phenolic compounds.

\section{Organic acids}

Statistically significant differences $(p<0.05)$ occurred among both cultivars and genotypes in terms of the concentration of organic acids (Tab. 5).

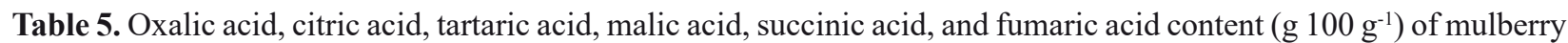
cultivars and genotypes (mean for 2014 and 2015)

\begin{tabular}{lllllll}
\hline $\begin{array}{l}\text { Cultivars and } \\
\text { genotypes }\end{array}$ & Oxalic acid & Citric acid & Tartaric acid & Malic acid & Succinic acid & Fumaric acid \\
\hline Ship Yeoung & $0.98 \pm 0.04 \mathrm{~b} *$ & $4.20 \pm 0.02 \mathrm{~b}$ & $0.79 \pm 0.01 \mathrm{a}$ & $7.78 \pm 0.17 \mathrm{ef}$ & $0.62 \pm 0.01 \mathrm{e}$ & $0.01 \pm 0.00 \mathrm{j}$ \\
Suwean Daeyap & $0.60 \pm 0.02 \mathrm{f}$ & $2.16 \pm 0.02 \mathrm{~g}$ & $0.51 \pm 0.02 \mathrm{~cd}$ & $6.03 \pm 0.05 \mathrm{hi}$ & $0.82 \pm 0.02 \mathrm{c}$ & $0.07 \pm 0.00 \mathrm{~g}$ \\
Roso & $1.00 \pm 0.04 \mathrm{~b}$ & $3.61 \pm 0.06 \mathrm{c}$ & $0.53 \pm 0.04 \mathrm{c}$ & $4.93 \pm 0.05 \mathrm{k}$ & $0.95 \pm 0.02 \mathrm{~b}$ & $0.01 \pm 0.00 \mathrm{j}$ \\
Yong Choenchoe & $0.68 \pm 0.03 \mathrm{e}$ & $2.67 \pm 0.03 \mathrm{f}$ & $0.49 \pm 0.02 \mathrm{~d}$ & $5.36 \pm 0.04 \mathrm{jk}$ & $0.82 \pm 0.04 \mathrm{c}$ & $0.04 \pm 0.00 \mathrm{~h}$ \\
Gosho Eromi & $1.18 \pm 0.05 \mathrm{a}$ & $3.03 \pm 0.08 \mathrm{e}$ & $0.65 \pm 0.01 \mathrm{~b}$ & $6.19 \pm 0.11 \mathrm{~h}$ & $0.83 \pm 0.03 \mathrm{c}$ & $0.01 \pm 0.00 \mathrm{j}$ \\
Thengxiang & $0.58 \pm 0.02 \mathrm{fg}$ & $3.23 \pm 0.06 \mathrm{~d}$ & $0.51 \pm 0.03 \mathrm{~cd}$ & $6.91 \pm 0.07 \mathrm{~g}$ & $0.68 \pm 0.01 \mathrm{de}$ & $0.01 \pm 0.01 \mathrm{j}$ \\
Kokusa 20 & $0.55 \pm 0.05 \mathrm{~g}$ & $1.96 \pm 0.06 \mathrm{~h}$ & $0.21 \pm 0.01 \mathrm{~h}$ & $5.69 \pm 0.05 \mathrm{ij}$ & $0.44 \pm 0.01 \mathrm{~g}$ & $0.03 \pm 0.01 \mathrm{hi}$ \\
He ye bar & $0.73 \pm 0.01 \mathrm{de}$ & $1.98 \pm 0.04 \mathrm{~h}$ & $0.26 \pm 0.01 \mathrm{~g}$ & $12.70 \pm 0.10 \mathrm{a}$ & $0.81 \pm 0.05 \mathrm{c}$ & $0.03 \pm 0.00 \mathrm{i}$ \\
23-mrk-09 & $0.39 \pm 0.02 \mathrm{hij}$ & $2.16 \pm 0.04 \mathrm{~g}$ & $0.43 \pm 0.03 \mathrm{e}$ & $8.82 \pm 0.04 \mathrm{~cd}$ & $0.70 \pm 0.02 \mathrm{~d}$ & $0.04 \pm 0.00 \mathrm{~h}$ \\
44-ba-05 & $0.16 \pm 0.011$ & $6.50 \pm 0.04 \mathrm{a}$ & $0.00 \pm 0.00 \mathrm{k}$ & $5.60 \pm 0.55 \mathrm{ij}$ & $0.48 \pm 0.02 \mathrm{~g}$ & $0.00 \pm 0.00 \mathrm{k}$ \\
Angut-Bayırbağ1 & $0.35 \pm 0.01 \mathrm{jk}$ & $0.82 \pm 0.01 \mathrm{~h}$ & $0.11 \pm 0.00 \mathrm{j}$ & $8.63 \pm 0.03 \mathrm{~d}$ & $0.68 \pm 0.01 \mathrm{de}$ & $0.12 \pm 0.01 \mathrm{e}$ \\
Elazı̆g-Çekirdekli & $0.57 \pm 0.02 \mathrm{fg}$ & $1.05 \pm 0.031$ & $0.17 \pm 0.01 \mathrm{i}$ & $3.70 \pm 0.031$ & $0.55 \pm 0.04 \mathrm{f}$ & $0.03 \pm 0.00 \mathrm{i}$ \\
İstanbul-dut $(24-10)$ & $0.71 \pm 0.05 \mathrm{de}$ & $0.97 \pm 0.03 \mathrm{~m}$ & $0.09 \pm 0.00 \mathrm{j}$ & $12.45 \pm 0.96 \mathrm{a}$ & $0.96 \pm 0.03 \mathrm{ab}$ & $0.13 \pm 0.01 \mathrm{~d}$ \\
44-MRK-05 & $0.34 \pm 0.02 \mathrm{k}$ & $0.70 \pm 0.04 \mathrm{o}$ & $0.00 \pm 0.00 \mathrm{k}$ & $10.77 \pm 0.11 \mathrm{~b}$ & $1.01 \pm 0.10 \mathrm{a}$ & $0.08 \pm 0.01 \mathrm{f}$ \\
Arapgir-0011 & $0.42 \pm 0.02 \mathrm{hi}$ & $2.16 \pm 0.06 \mathrm{~g}$ & $0.17 \pm 0.01 \mathrm{i}$ & $9.12 \pm 0.05 \mathrm{c}$ & $0.66 \pm 0.05 \mathrm{de}$ & $0.21 \pm 0.01 \mathrm{a}$ \\
Arapgir-0012 & $0.43 \pm 0.03 \mathrm{~h}$ & $1.85 \pm 0.03 \mathrm{i}$ & $0.82 \pm 0.02 \mathrm{a}$ & $8.78 \pm 0.34 \mathrm{~cd}$ & $0.50 \pm 0.01 \mathrm{fg}$ & $0.18 \pm 0.01 \mathrm{~b}$ \\
44-KE-10 & $0.42 \pm 0.03 \mathrm{hi}$ & $1.51 \pm 0.05 \mathrm{j}$ & $0.36 \pm 0.01 \mathrm{f}$ & $7.51 \pm 0.04 \mathrm{f}$ & $0.95 \pm 0.02 \mathrm{~b}$ & $0.07 \pm 0.01 \mathrm{~g}$ \\
24-MRK-01 & $0.38 \pm 0.02 \mathrm{ijk}$ & $2.12 \pm 0.05 \mathrm{~g}$ & $0.38 \pm 0.02 \mathrm{f}$ & $7.77 \pm 0.04 \mathrm{ef}$ & $0.94 \pm 0.03 \mathrm{~b}$ & $0.07 \pm 0.01 \mathrm{~g}$ \\
24-KE-05 & $0.79 \pm 0.02 \mathrm{c}$ & $1.16 \pm 0.01 \mathrm{k}$ & $0.36 \pm 0.01 \mathrm{f}$ & $8.03 \pm 0.06 \mathrm{e}$ & $0.96 \pm 0.04 \mathrm{ab}$ & $0.17 \pm 0.00 \mathrm{c}$ \\
\hline
\end{tabular}

*Difference between means designated with the same letter in the same column is not significant at 0.05 level 
Malic acid and citric acid were dominant organic acids in the fruits of all the mulberry cultivars and genotypes. They were followed by oxalic acid, succinic acid, tartaric acid, and fumaric acid. The concentrations of malic acid and citric acid were

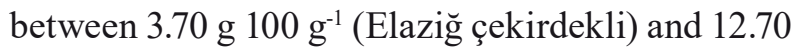
g $100 \mathrm{~g}^{-1}$ (He ye bar and Istanbul dut), and $0.70 \mathrm{~g}$

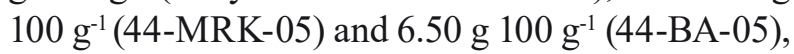
respectively (Tab. 5). In parallel to this study, Ozgen et al. (2009) from Turkey and Sanchez et al. (2014) from Spain determined that malic and citric acid from among the organic acids found in mulberry fruits were the most abundant. Eyduran et al. (2015) reported that malic acid was the dominant organic acid in mulberry fruits, with a concentration

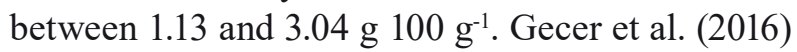
stated that the highest values of malic acid found in black and white mulberries were 3.07 and $2.13 \mathrm{~g} 100$ $\mathrm{g}^{-1}$, respectively. Gundogdu et al. (2011) measured citric acid and malic acid in black mulberries as

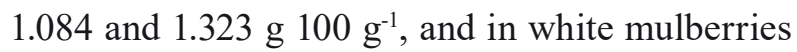

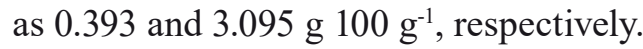

The highest oxalic acid content was $1.18 \mathrm{~g} 100$ $\mathrm{g}^{-1}$ in the Gosho aromi cultivar and its lowest value was $0.16 \mathrm{~g}^{-1}$ in the 44-Ba-05 genotype. On the other hand, the 44-Ba-05 genotype had the highest citric acid content, while the 44-nrk-05 genotype had the lowest value. Tartaric acid content was measured

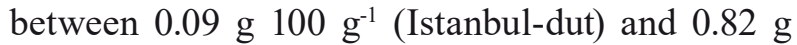
$100 \mathrm{~g}^{-1}$ (Arapgir-0012). However, the difference in tartaric acid content between the Arapgir-0012 genotype and the cultivar Ship yeoung was not significant. There was also no significant difference between the Istanbul-dut genotype and the Angut genotype. In two samples tartaric acid was not detected. The highest succinic acid content was $1.01 \mathrm{~g}^{100 \mathrm{~g}^{-1}}$ in 44-MRK-05, and its lowest value

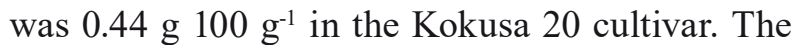
fumaric acid content was determined to vary among all the cultivars and genotypes in the range of $0.01 \mathrm{~g}$

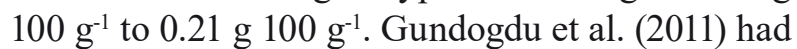
measured tartaric acid, succinic acid, and fumaric acid in black mulberries as $0.123,0.342$ and $0.011 \mathrm{~g}$ $100 \mathrm{~g}^{-1}$, and in white mulberries as $0.223,0.168$, and

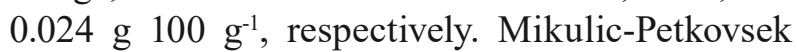
et al. (2012) measured the fumaric acid content in mulberry fruits at the lowest level. They determined the concentrations of citric acid, tartaric acid, succinic acid and fumaric acid in mulberry fruits

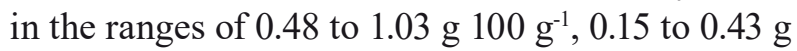

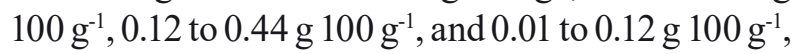
respectively. The differences in the concentration of organic acids might be associated with factors such as genetic factors, cultivation practices, climatic conditions, and soil structure (Ruttanaprasert et al. 2014). The organic acid content is a determinant of fruit taste depending on the acid-sugar balance. Organic acids in fruits and vegetables mostly occur in a free form or are combined as salts, esters or glycosides (Cemeroğlu and Acar 1986). In addition to imparting taste to fruits, organic acids are among the chemicals that also have a vital importance in protecting human health. It has been understood in some studies that organic acids, especially malic acid, citric acid and tartaric acid, make significant contributions to human health in several respects such as enhancing the immune system, preventing the formation of kidney stones, eliminating oral diseases, reducing the risk of poisoning by toxic metals, beautifying and strengthening of the skin, and reducing fibromyalgia symptoms (Abraham and Flechas 1992, Penniston et al. 2007).

\section{Vitamin C}

Differences were observed between the cultivars and genotypes in terms of vitamin $\mathrm{C}$ content (Tab. 6). The highest vitamin $\mathrm{C}$ content was measured as $31.34 \mathrm{mg} 100 \mathrm{~g} \mathrm{~g}^{-1}$ in the Thengxtang cultivar; it had the lowest values in the Suwean daeyap cultivar and the 24-MRK-01 genotype as

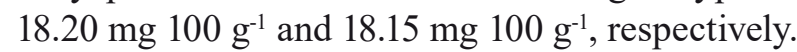
Lale and Ozcagiran (1996) had measured the vitamin $\mathrm{C}$ content in black and purple mulberries as 16.6 and $11.9 \mathrm{mg} 100 \mathrm{~mL}^{-1}$, respectively. Ercisli and Orhan (2008) stated that the vitamin C content of fruits taken from black mulberry genotypes grown in the Northeast Anatolia Region of Turkey varied between 14.9 and $18.8 \mathrm{mg} 100 \mathrm{~mL}^{-1}$. Ercisli and Orhan (2007) reported the vitamin C content in white, red, and black mulberries as 22.4, 19.4, and $21.8 \mathrm{mg} 100 \mathrm{~mL}^{-1}$, respectively. In another study, the vitamin $\mathrm{C}$ content of black and purple mulberry fruits was measured as 20.79 and $18.87 \mathrm{mg} 100 \mathrm{~mL}^{-1}$, respectively (Ercisli et al. 2010). Imran et al. (2010) reported that white and black mulberries contained vitamin $C$ in the amount of 15.20 and $15.37 \mathrm{mg}$ $100 \mathrm{~g}^{-1}$, respectively. In a study conducted by Eyduran et al. (2015) to analyze the fruits of white and black mulberries, vitamin $\mathrm{C}$ content ranged from 10.12 to $18.22 \mathrm{mg} 100 \mathrm{~g}^{-1}$. Gecer et al. (2016) found the vitamin $\mathrm{C}$ content of white and black mulberries

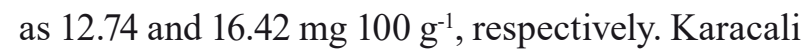
(2012) mentioned that fruit types could be classified into three groups: poor, average, or rich in terms of vitamin $\mathrm{C}$ content, and in this respect mulberry fruits are generally assigned to the group which is 
Table 6. Vitamin C, total antioxidant capacity (TEAC), and sugar content of mulberry cultivars and genotypes (mean for 2014 and 2015)

\begin{tabular}{|c|c|c|c|c|c|}
\hline $\begin{array}{l}\text { Cultivars and } \\
\text { genotypes }\end{array}$ & $\begin{array}{l}\text { Vitamin C } \\
\left(\mathrm{mg} 100 \mathrm{~g}^{-1}\right)\end{array}$ & $\begin{array}{c}\text { TEAC } \\
\left(\mu \mathrm{mol} \mathrm{TE*} \mathrm{g}^{-1}\right)\end{array}$ & $\begin{array}{l}\text { Glucose } \\
\left(\mathrm{g}^{\left.100 \mathrm{~g}^{-1}\right)}\right.\end{array}$ & $\begin{array}{l}\text { Fructose } \\
\left({\left.\mathrm{g} 100 \mathrm{~g}^{-1}\right)}\right.\end{array}$ & $\begin{array}{l}\text { Sucrose } \\
\left(\mathrm{g} 100 \mathrm{~g}^{-1}\right)\end{array}$ \\
\hline Ship Yeoung & $22.13 \pm 0.00 \mathrm{f}^{* *}$ & $15.19 \pm 0.07 f$ & $8.15 \pm 0.11 b$ & $7.11 \pm 0.04 b$ & $1.35 \pm 0.03 \mathrm{c}$ \\
\hline Suwean Daeyap & $18.20 \pm 0.06 n$ & $13.13 \pm 0.09 j$ & $7.22 \pm 0.03 \mathrm{~d}$ & $5.15 \pm 0.02 \mathrm{~g}$ & $0.92 \pm 0.01 \mathrm{ghi}$ \\
\hline Roso & $19.38 \pm 0.031$ & $11.13 \pm 0.08 \mathrm{k}$ & $6.24 \pm 0.06 \mathrm{~h}$ & $5.07 \pm 0.05 \mathrm{~g}$ & $0.88 \pm 0.02 \mathrm{ij}$ \\
\hline Yong Choenchoe & $21.35 \pm 0.03 \mathrm{gh}$ & $13.57 \pm 0.09 \mathrm{~h}$ & $8.17 \pm 0.04 b$ & $6.23 \pm 0.04 d$ & $1.34 \pm 0.04 \mathrm{c}$ \\
\hline Gosho Eromi & $29.31 \pm 0.07 b$ & $8.23 \pm 0.02 \mathrm{o}$ & $7.70 \pm 0.09 \mathrm{c}$ & $6.11 \pm 0.03 \mathrm{~d}$ & $1.14 \pm 0.05 \mathrm{~d}$ \\
\hline Thengxiang & $31.34 \pm 0.01 \mathrm{a}$ & $18.35 \pm 0.11 b$ & $7.07 \pm 0.06 \mathrm{e}$ & $5.84 \pm 0.09 \mathrm{e}$ & $0.96 \pm 0.01 \mathrm{~g}$ \\
\hline Kokusa 20 & $22.17 \pm 0.01 \mathrm{f}$ & $15.18 \pm 0.04 \mathrm{f}$ & $6.93 \pm 0.06 \mathrm{f}$ & $5.30 \pm 0.03 f$ & $1.08 \pm 0.04 \mathrm{ef}$ \\
\hline He ye bar & $21.14 \pm 0.00 \mathrm{hi}$ & $14.17 \pm 0.06 \mathrm{~g}$ & $6.41 \pm 0.07 \mathrm{~g}$ & $4.55 \pm 0.21 \mathrm{~h}$ & $0.90 \pm 0.04 \mathrm{hij}$ \\
\hline 23-mrk-09 & $25.14 \pm 0.01 \mathrm{~d}$ & $6.17 \pm 0.03 p$ & $5.20 \pm 0.07 i$ & $4.10 \pm 0.01 \mathrm{i}$ & $0.94 \pm 0.01 \mathrm{gh}$ \\
\hline 44-ba-05 & $18.48 \pm 0.20 \mathrm{~m}$ & $9.84 \pm 0.04 \mathrm{~m}$ & $5.30 \pm 0.06 \mathrm{i}$ & $5.11 \pm 0.03 \mathrm{~g}$ & $1.14 \pm 0.02 \mathrm{~d}$ \\
\hline Angut-Bayırbağ 1 & $26.26 \pm 0.38 \mathrm{c}$ & $15.31 \pm 0.02 \mathrm{e}$ & $7.19 \pm 0.05 \mathrm{~d}$ & $6.23 \pm 0.06 \mathrm{~d}$ & $1.10 \pm 0.02 \mathrm{de}$ \\
\hline Elazı̆ğ-Çekirdekli & $19.47 \pm 0.221$ & $13.13 \pm 0.02 \mathrm{j}$ & $6.15 \pm 0.03 \mathrm{~h}$ & $5.17 \pm 0.04 \mathrm{~g}$ & $1.07 \pm 0.06 \mathrm{ef}$ \\
\hline İstanbul-dut (24-10) & $22.56 \pm 0.01 \mathrm{e}$ & $16.25 \pm 0.04 d$ & $8.09 \pm 0.08 b$ & $6.79 \pm 0.07 \mathrm{c}$ & $1.32 \pm 0.04 \mathrm{c}$ \\
\hline 44-MRK-05 & $21.46 \pm 0.02 \mathrm{~g}$ & $18.07 \pm 0.06 \mathrm{c}$ & $5.20 \pm 0.06 \mathrm{i}$ & $4.19 \pm 0.08 \mathrm{i}$ & $0.85 \pm 0.02 \mathrm{j}$ \\
\hline Arapgir-0011 & $20.46 \pm 0.06 \mathrm{j}$ & $11.10 \pm 0.02 \mathrm{k}$ & $7.19 \pm 0.06 \mathrm{~d}$ & $5.87 \pm 0.11 \mathrm{e}$ & $1.14 \pm 0.03 \mathrm{~d}$ \\
\hline Arapgir-0012 & $19.41 \pm 0.301$ & $13.24 \pm 0.03 i$ & $5.19 \pm 0.03 \mathrm{i}$ & $4.12 \pm 0.01 \mathrm{i}$ & $0.95 \pm 0.02 \mathrm{gh}$ \\
\hline 44-KE-10 & $21.03 \pm 0.03 \mathrm{i}$ & $9.13 \pm 0.05 n$ & $6.24 \pm 0.06 \mathrm{~h}$ & $5.15 \pm 0.11 \mathrm{~g}$ & $1.04 \pm 0.04 \mathrm{f}$ \\
\hline 24-MRK-01 & $18.15 \pm 0.03 n$ & $10.11 \pm 0.051$ & $9.22 \pm 0.09 \mathrm{a}$ & $7.90 \pm 0.04 \mathrm{a}$ & $1.60 \pm 0.03 b$ \\
\hline 24-KE-05 & $19.73 \pm 0.02 \mathrm{k}$ & $21.13 \pm 0.06 \mathrm{a}$ & $8.18 \pm 0.07 b$ & $6.87 \pm 0.12 \mathrm{c}$ & $1.91 \pm 0.05 \mathrm{a}$ \\
\hline
\end{tabular}

*TE - Trolox equivalent

**Difference between means designated with the same letter in the same column is not significant at 0.05 level

designated as the average group in terms of vitamin C content.

\section{Antioxidant activity}

Total antioxidant capacity (TEAC) results for mulberry fruits are given in Table 6. There were statistically significant differences between the cultivars and genotypes $(p<0.05)$. The TEAC content was determined to be between $6.17 \mu \mathrm{mol}$ TE g ${ }^{-1}$ (23-MRK-09 genotype) and $21.13 \mu \mathrm{mol}$ TE $\mathrm{g}^{-1}$ (24-KE-05 genotype) (Tab. 6). Gundogdu et al. (2011) had reported that black mulberries had higher TEAC values compared to white mulberries. Gungor and Sengul (2008) reported that antioxidant capacity in white mulberries varied between 18.16 and 19.24 $\mu \mathrm{mol} \mathrm{TE} \mathrm{g}{ }^{-1}$. Ozgen et al. (2009) measured antioxidant activity in black mulberries in the range of 6.8 to $14.4 \mu \mathrm{mol} \mathrm{TE} \mathrm{g}$. . Eyduran et al. (2015) indicated that there was variation among mulberry genotypes in terms of total antioxidant capacity, which was measured between 6.17 and $14.40 \mu \mathrm{mol}$ TE $\mathrm{g}^{-1}$, and that black mulberries had a higher TEAC value compared to white mulberries. In parallel with this, Gecer et al. (2016) also reported that black mulberries had a higher TEAC value (9.17 $\mu$ mol TE g $\left.{ }^{-1}\right)$ than white mulberries $(6.17 \mu$ mol TE $\left.\mathrm{g}^{-1}\right)$. A significant difference in terms of antioxidant capacity has been observed between white and black mulberries grown in Spain (Sanchez et al. 2014). The health importance of mulberry fruits has increased recently because of their potential for high antioxidant activity (Sanchez et al. 2014). Therefore, mulberry genotypes (especially the 24-KE-05 genotype) have been found to be important for high antioxidant content, and we believe that this will help mulberry breeders who are interested in developing elite cultivars with high antioxidant capacity.

\section{Sugars}

In this study, the concentrations of glucose, fructose, and sucrose, which are essential sugars in mulberry fruits, were determined and the differences between the cultivars and genotypes were revealed (Tab. 6). The level of sucrose was measured to be lower than that of the other sugars. The highest values in terms of glucose and fructose content were obtained for the 24-MRK-01 genotype

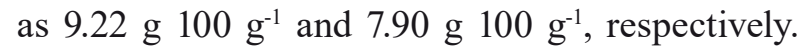
The highest sucrose content was also determined

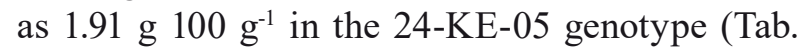


6). Previously, great differences had been observed between genotypes and cultivars in terms of sugar content in fruit samples taken from mulberry trees in different countries. In Spain, Sanchez et al. (2014) determined the glucose content and fructose content of fully ripened white mulberries

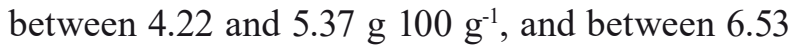

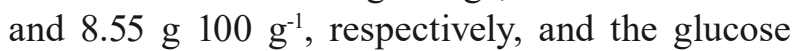
content and fructose content of black mulberries

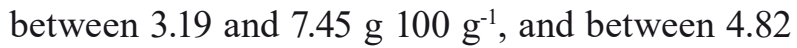

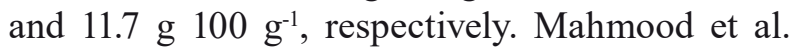
(2012) measured the glucose and fructose contents of black mulberries harvested when fully ripe in the climatic conditions of Pakistan as 2.50 and 5.36 g $100 \mathrm{~g} \mathrm{~g}^{-1}$, and the glucose and fructose contents

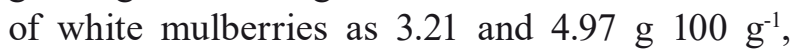
respectively. Eyduran et al. (2015) determined that the glucose content of fruits taken from all black and white mulberry genotypes was higher than the fructose content, with the highest glucose and fructose concentrations of 9.44 and $7.70 \mathrm{~g} 100 \mathrm{~g} \mathrm{~g}^{-1}$, respectively, obtained from white mulberries. Gecer et al. (2016) evaluated black and white mulberries and found higher levels of fructose (8.16 and 7.69 g $100 \mathrm{~g} \mathrm{~g}^{-1}$, respectively) and glucose (9.55 and 8.31 g $100 \mathrm{~g}^{-1}$, respectively). In Spain, the determined values were highest for fructose and glucose and lowest for sucrose (Sanchez et al. 2014). Ozgen et al. (2009) stated that the fructose and glucose contents of fourteen black and red mulberry genotypes

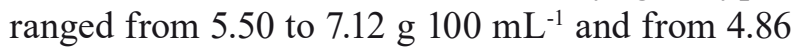

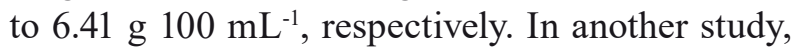
Mikulic-Petkovsek et al. (2012) indicated that glucose and fructose determined in 25 wild and cultivated mulberries were more abundant, and the glucose content of black mulberry fruits growing

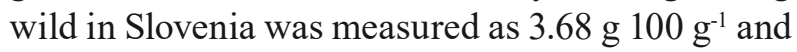

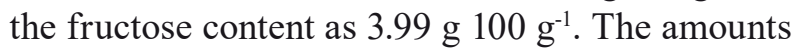
of sugars determined in the fruits of mulberry cultivars and genotypes vary depending on genetic factors, cultivation practices, and environmental conditions (Gundogdu et al. 2011).

\section{CONCLUSIONS}

1. In the presented study, attempt was made to optimize the effects of various factors on the biochemical content of mulberry fruits by growing mulberry cultivars and genotypes under the same environmental conditions and in a place where the same cultivation practices were implemented. Therefore, only the genetic differences among the cultivars and genotypes were effective in determining the biochemical content of fruits, and those differences were found to be statistically significant $(p<0.05)$ when the results obtained for the phytochemical content of the analyzed mulberry fruits were examined.

2. Examined mulberry cultivars and genotypes were found to be rich in phenolic compounds such as chlorogenic acid, caffeic acid, $p$-coumaric acid, and $o$-coumaric acid, which are especially known for anti-cancer, anti-fungal, allelopathic, and anti-microbial characteristics. According to the results of numerous studies, this is thought to provide positive influence for increasing the value and consumption of mulberry fruits, as a source of phytochemicals with important benefits in terms of nutrition and health. In addition to providing benefits for both producers and consumers, this will also contribute to the development of improvement studies and industries related to these fruits.

3. It is thought that the results obtained in this study are important in terms of being a source for further studies and revealing nutritional values of world gene pools. This study has a unique quality in terms of revealing relations of these phytochemicals with their corresponding genes and developing new cultivars by conducting genetic improvement studies. In addition, the paper describes the genotypic response of some mulberry genotypes from Anatolia in respect of some biochemical properties and we believe that it will help international mulberry breeders who are interested in developing elite cultivars with better qualities as these genotypes might be used as parents in mulberry breeding.

\section{AUTHOR CONTRIBUTIONS}

M.G., I.C, M.K.G, T.K. and S.E. - contributed equally to this work.

\section{CONFLICT OF INTEREST}

Authors declare no conflict of interest.

\section{REFERENCES}

Abraham G.E., Flechas J.D., 1992. Management of fibromyalgia: rationale for the use of magnesium and malic acid. J. Nutr. Med. 3: 49-59.

Bevilacqua A.E., Califano A.N., 1989. Determination of organic acids in dairy products by high performance liquid chromatography. J. Food Sci. 54: 1076-1079. 
Butt M.S., Nazir A., Sultan M.T., Schrö̈N K., 2008. Morus alba L. nature's functional tonic. Trends Food Sci. Technol. 19: 505-512.

ÇAм M., HışıL Y., 2004. Gıda flavonoidlerinin yüksek basınç sıvı kromatografisi ile analizi. Akademik Gida Der. 8: 22-25 (in Turkish).

Canan I., Gundogdu M., Seday U., Oluk C.A., Karasahin Z., Eroglu E.C., Yazici E., Ünlü M., 2016. Determination of antioxidant total phenolic, total carotenoid, lycopene, ascorbic acid, and sugar contents of Citrus species and mandarin hybrids. Turk. J. Agric. For. 40: 894-899.

Cemeroglu B., 2007. Gida Analizleri [Food Analysis]. Food Technology Society Publication, Ankara, Turkey, 168-171 (in Turkish).

CemeroĞlu B., Acar J., 1986. Meyve ve sebze isleme teknolojisi. Gida Tek. Der. 6: 29-30 (in Turkish).

ERCisLi S., 2004. A short review of the fruit germplasm resources of Turkey. Genet. Res. Crop Evol. 51: 419435.

Ercisli S., Orhan E., 2007. Chemical composition of white (Morus alba), red (Morus rubra) and black (Morus nigra) mulberry fruits. Food Chem. 103: 1380-1384.

Ercisli S., Orhan E., 2008. Some physico-chemical characteristics of black mulberry (Morus nigra L.) genotypes from Northeast Anatolia region of Turkey. Sci. Hort. 116: 41-46.

Ercisli S., Tosun M., Duraliua B., Voca S., Sengul M., Turan M., 2010. Phytochemical content of some black (Morus nigra L.) and purple (Morus rubra L.) mulberry genotypes. Food Technol. Biotechnol. 48(1): 102-106.

Eyduran S.P., Ercisli S., Akin M., Beyhan O., Gecer M.K., Eyduran E., Erturk Y.E., 2015. Organic acids, sugars, vitamin $\mathrm{C}$, antioxidant capacity, and phenolic compounds in fruits of white (Morus alba L.) and black (Morus nigra L.) mulberry genotypes. J. Appl. Bot. Food Qual. 88: 134-138.

Gecer M.K., Akin M., Gundogdu M., Eyduran S.P., ERCisli S., Eyduran E., 2016. Organic acids, sugars, phenolic compounds, and some horticultural characteristics of black and white mulberry accessions from Eastern Anatolia. Can. J. Plant Sci. 96: 27-33.

Gundogdu M., Muradoglu F., Sensoy R.I.G., Yilmaz H., 2011. Determination of fruit chemical properties of Morus nigra L., Morus alba L. and Morus rubra L. by HPLC. Sci. Hort. 132: 37-41.

Gungor N., Sengul M., 2008. Antioxidant activity, total phenolic content and selected physicochemical properties of white mulberry (Morus alba L.) fruits. Int. J. Food Prop. 11: 44-52.

Hegedus A., Engel R., Abrankó L., Balogh E., Blázovics A., Hermán R., Halász J., Ercisli S., Pedryc A., Stefanovits-Bányai É., 2010. Antioxidant and antiradical capacities in apricot (Prunus armeniaca L.) fruits: variations from genotypes, years, and analytical methods. J. Food Sci. 75: C722-730.

Imran M., Khan H., Shah M., Khan R., Khan F., 2010. Chemical composition and antioxidant activity of certain Morus species. J. Zhejiang Univ. Sci. B. 11(12): 973-980.

KARACALI I., 2012. Storage and marketing of horticultural products. Ege University Agricultural Faculty Publication No. 494 Izmir, Turkey (in Turkish).

Koyuncu F., Cetinbas M., Ibrahim E., 2014. Nutritional constituents of wild-grown black mulberry (Morus nigra L.). J. Appl. Bot. Food Qual. 87: 93-96.

Lale H., Ozcagiran R., 1996. A study on pomological, phenological and fruit quality characteristics of mulberry (Morus sp.) species. Derim. 13: 177-182 (in Turkish).

Mahmood T., Anwar F., Abbas M., Boyce M.C., SAARI N., 2012. Compositional variation in sugars and organic acids at different maturity stages in selected small fruits from Pakistan. Int. J. Mol. Sci. 13(2): 1380-1392.

Melgarejo P., Salazar D.M., Artes F., 2000. Organic acids and sugars composition of harvested pomegranate fruits. Eur. Food Res. Technol. 211: 185-190.

Memon A.A., Memon N., Luthria D.L., Bhanger M.I., Pitafi A.A., 2010. Phenolic acids profiling and antioxidant potential of mulberry (Morus laevigata W., Morus nigra L., Morus alba L.) leaves and fruits grown in Pakistan. Pol. J. Food Nutr. Sci. 60: 25-32.

Mikulic-Petkovsek M., Schmitzer V., Slatnar A., Stampar F., Veberic R., 2012. Composition of sugars, organic acids, and total phenolics in 25 wild or cultivated berry species. J. Food Sci. 77: C10641070.

Orhan E., Ercisli S., 2010. Genetic relationships between selected Turkish mulberry genotypes (Morus spp.) based on RAPD markers. Genet. Mol. Res. 9: 2176-2183.

Ozgen M., Reese R.N., Tulio A.Z., Scheerens J.C., Miller A.R., 2006. Modified 2,2-Azino-bis-3ethylbenzothiazoline-6-sulfonic Acid (ABTS) method to measure antioxidant capacity of selected small fruits and a comparison to Ferric Reducing Antioxidant Power (FRAP) and 2,2-Diphenyl-1picrylhdrazyl (DPPH) methods. J. Agric. Food Chem. 54: 1151-1157.

Ozgen M., Serce S., Kaya C., 2009. Phytochemical and antioxidant properties of anthocyanin-rich Morus nigra and Morus rubra fruits. Sci. Hort. 119: 275 279.

Penniston K.L., Steele T.H., Nakada S.Y., 2007. Lemonade therapy increases urinary citrate and urine volumes in patients with recurrent calcium oxalate stone formation. Urology 70(5): 856-860.

Rodriguez-Delgado M.A., Malovana S., Perez J.P., Borges T., Garcia Montelongo F.J., 
2001. Separation of phenolic compounds by high-performance liquid chromatography with absorbance and fluorimetric detection. J. Chrom. A. 912: 249-257.

Rodriguez-Mateos A., Vauzour D., Krueger C.G., Shanmuganayagam D., Reed J., Calani L., Mena P., Del Rio D., Crozier A., 2014. Bioavailability, bioactivity and impact on health of dietary flavonoids and related compounds: an update. Arch Toxicol. 88(10): 1803-1853.

Ruttanaprasert R., Banterng P., Jogloy S., Vorasoot N., Kesmala T., Kanwar R.S., Holbrook C.C., Patanothai A., 2014. Genotypic variability for tuber yield, biomass, and drought tolerance in Jerusalem artichoke germplasm. Turk. J. Agric. For. 38: 570-580.

Sanchez E.M., Calin-Sanchez A., CarbonellBarrachina A.A., Melgarejo P., Hernandez F., Martinez-Nicolas J.J., 2014. Physicochemical characterization of eight Spanish mulberry clones: Processing and fresh market aptitudes. Int. J. Food Sci. Technol. 49: 477-483.

Sanchez-Salcedo E.M., Mena P., Garcia-Viguera C., Martinez J.J., Hernandez F., 2015. Phytochemical evaluation of white (Morus alba L.) and black (Morus nigra L.) mulberry fruits, a starting point for the assessment of their beneficial properties. J. Funct. Foods 12: 399-408.

SorkheH K., Khaleghi E., 2016. Molecular characterization of genetic variability and structure of olive (Olea europaea L.) germplasm collection analyzed by agromorphological traits and microsatellite markers. Turk. J. Agric. For. 40: 583596.

Soyer Y., Koca N., Karadeniz F., 2003. Organic acid profile of Turkish white grapes and grape juices. J. Food Comp. Anal. 16: 629-636.

TSI, 2016. Turkish Statistical Institute, Dynamic Examination Vegetative Production Statistics https://biruni.tuik.gov.tr/bitkiselapp/bitkisel.zul; cited on 29 July 2016.

Zadernowski R., NaczK M., Nesterowicz J., 2005. Phenolic acid profiles in some small berries. J. Agric. Food Chem. 53: 2118-2124.

Zorenc Z., Veberic R., Stampar F., Koron D., Mikulic-PetkovseK M., 2016. Changes in berry quality of northern highbush blueberry (Vaccinium corymbosum L.) during the harvest season. Turk. J. Agric. For. 40: 855-867.

Received August 14, 2017; accepted October 18, 2017 